\title{
An Analysis of the Intelligent Interactive Mode of College English Based on Superstar Learning
}

\author{
Aihua Liu ${ }^{1}$, Dehua Kong ${ }^{2, *}$, ZhuoWei Wang ${ }^{3}$ \\ ${ }^{1}$ School of Foreign Language and Literature, Wuhan Donghu University, Wuhan, China \\ ${ }^{2,3}$ School of Computer Science, Wuhan Donghu University, Wuhan, China
}

\begin{abstract}
As a product of the in-depth integration of information technology and classroom teaching, smart classroom is the carrier of intelligent interactive mode, which can realize classroom structure reform and precise teaching. Intelligent interactive mode is a new way and choice of college teaching at present. The exploration of intelligent interactive mode and the application of intelligent interaction in the three aspects of college English courses show that the intelligent interactive mode has a promoting effect on the intelligence of college English classroom teaching and the development of personality.
\end{abstract}

\section{Introduction}

In the process of collision between information technology, big data and my country's education system, the study of college English learning modes has also entered an era of information and digitalization. When students face many difficulties in their English learning, big data analysis provides the most appropriate information platform for studying the integration and updating of Chinese college students' English learning modes. With the rapid development of mobile internet technology and the advancement of education informatization, school teaching modes are constantly changing. A new type of classroom form comes into being with mobile internet technology, cloud computing, big data and other information technologies. It is the product of the deep integration of information technology and classroom teaching-smart classroom. As the carrier of intelligent interactive mode, smart classroom makes college English teaching more intelligent and personalized.

\section{College English Smart Class}

\subsection{The Connotation of College English Smart Class}

Smart classroom is the product of the extensive application of the Internet of Things, cloud computing, and big data in education and teaching. It is a classroom form that integrates a new generation of information technology and classroom teaching. It uses humancomputer synergy to build an ecological learning environment through technology integration. A classroom-teaching paradigm that optimizes the teaching process and promotes the development of students' wisdom. The application of smart classrooms in college English teaching aims to realize data based English teaching decision-making, instant evaluation and feedback, convenient interactive communication, and diversified resource push. Smart classrooms can better serve students and make their English learning more intelligent and personalized.

\subsection{The Characteristics of College English Smart Classroom}

\subsubsection{The Intelligent Environment Realizes the Reform of Classroom Structure}

- Changes in teaching mode. The smart learning environment makes the teacher's "one-speaking" mode in traditional classrooms gone forever. The traditional teaching model is teacher-centered and the students lack initiative in learning; the smart classroom creates an environment where "learning" is the mainstay, studentcentered, and active learning is the goal. Students use information equipment and methods to learn English knowledge points before class, discuss problems and digest knowledge in class, and consolidate knowledge through homework or group tasks after class.

- Changes in the roles of teachers and students. Due to the changes in teaching mode and classroom structure, the roles of teachers and students in the teaching process have also changed. The teacher has changed from the imparter of knowledge to the guide of the student's learning; and the student has changed from the passive object of listening to the active object of learning. Only by studying carefully before class can they effectively participate in the discussion in the class. The internalization of knowledge can accurately complete the tasks after class. The tightly linked mode effectively 
improves the efficiency and consciousness of students' learning.

- Changes in students' learning styles. A smart learning environment has the greatest impact on students' learning styles. With the assistance of information technology and mobile devices, learning has changed from a traditional single listening and interactive mode to an intelligent and personalized learning mode and an intelligent interactive mode. With the assistance of smart tools, students have a variety of ways to learn English and a large number of learning resources can be used to assist learning, such as topic discussions, questionnaire surveys, group tasks, live broadcasts, etc. Through Chaoxing Learning Pass software, this can effectively improve the students' interest of English learning, and make English learning more effective.

\subsubsection{Smart Environment to Achieve Precise Teaching}

Another advantage of the smart environment is the whole process of data recording, statistics and analysis. Data analysis is completed while human-computer interaction, real-time evaluation and feedback are realized. Through these feedbacks, the teachers can adjust the teaching plan in time, update the teaching content, optimize the teaching strategy, and complete the teaching goal more pertinently. For example, through the smart tool Chaoxing Learning Link, you can horizontally and vertically analyze statistics and fully grasp the overall situation of the class and the specific situation of individual students. Chaoxing Learning Pass implements vertical statistics such as score management, student visits, student management, classroom activities, classroom points, etc. It also realizes the completion of individual student task points, video viewing details, discussion details, score details, chapter test statistics, homework exams Statistics and other horizontal statistics. With the support of its back-end cloud storage, cloud computing and other technologies, smart tools can help teachers fully grasp the academic report and achieve accurate teaching.

\section{Intelligent Interaction Mode}

As the carrier of the intelligent interactive mode, the smart classroom has a great influence on the interactive mode in the teaching process. Interaction between people (between teachers and students, between students and students) refers to the communication and interaction between people through language behavior. In the process of language teaching, language learning through interactive behavior is a means to improve learning effects and quickly master language ability. However, in traditional language teaching, the interaction behavior is single, which is only limited to the situational dialogue practice between students and teachers or students; in the era of multimedia teaching, human-computer interaction is realized, but it is also a one-way activity. Human instructions output information in one direction. For English teaching, human-computer interaction is a means of using multimedia equipment to transmit text, pictures, videos and other English knowledge to students. It lacks flexibility and mobility. Compared with the traditional teaching interactive mode, although it improves to a certain degree of efficiency, but did not substantially change the way of interaction. As shown in Table 1, in the process of teaching development, the interactive mode is constantly evolving and changing.

Table 1 Comparison of the development of interactive modes

\begin{tabular}{|l|l|l|l|}
\hline $\begin{array}{l}\text { Types of } \\
\text { Class }\end{array}$ & $\begin{array}{l}\text { interactive } \\
\text { mode }\end{array}$ & $\begin{array}{l}\text { Interactive } \\
\text { behavior } \\
\text { characteristics }\end{array}$ & $\begin{array}{l}\text { Interaction } \\
\text { condition }\end{array}$ \\
\hline $\begin{array}{l}\text { Traditional } \\
\text { classroom }\end{array}$ & $\begin{array}{l}\text { Human } \\
\text { interaction }\end{array}$ & single & $\begin{array}{l}\text { Face to } \\
\text { face }\end{array}$ \\
\hline $\begin{array}{l}\text { Multimedia } \\
\text { classroom }\end{array}$ & $\begin{array}{l}\text { Human- } \\
\text { human } \\
\text { interaction, } \\
\text { human- } \\
\text { computer } \\
\text { interaction } \\
\text { (one-way) }\end{array}$ & $\begin{array}{l}\text { One-way, } \\
\text { asynchronous }\end{array}$ & $\begin{array}{l}\text { multi- } \\
\text { media } \\
\text { equipment }\end{array}$ \\
\hline $\begin{array}{l}\text { Smart } \\
\text { classroom }\end{array}$ & $\begin{array}{l}\text { Human- } \\
\text { human } \\
\text { interaction, } \\
\text { human- } \\
\text { computer } \\
\text { interaction } \\
\text { two-way) }\end{array}$ & $\begin{array}{l}\text { Intelligent, } \\
\text { precise and } \\
\text { individual }\end{array}$ & $\begin{array}{l}\text { Smart } \\
\text { terminal, } \\
\text { big data, } \\
\text { cloud } \\
\text { computing }\end{array}$ \\
\hline
\end{tabular}

Nowadays, intelligent interaction mode is a new way and choice of teaching in colleges and universities. Whether it is human-human interaction or humancomputer interaction, with the assistance of intelligent technology, the learning subject and learning content, teachers or their own knowledge can be well realized. The benign interaction in aspects such as, emotion, and ability reflects the promotion of college English teaching. The intelligent interaction mode has obvious characteristics of Internet intelligence. Human-computer interaction and human-human interaction in the intelligent interaction mode are not only the interaction of behavior and language between humans and virtual technology and simulation technology, but also a new type of interactive communication between people through new technologies. In addition to human-to-human interaction in the intelligent interaction mode, there are also interactions between humans and mobile terminals, mobile terminals and smart technologies (big data, cloud computing, cloud storage, etc.), which enrich the ways of interaction and increase Improve the efficiency of interaction.

\subsection{Practical Conditions of Intelligent Interaction Mode}

In the teaching process, interactive behavior means that the learner and the learning environment realize their own development through mutual communication and interaction, which is the process attribute of learning and teaching. In the process of college English teaching, interactive activities include not only the teaching of teachers, but also the learning of students, which is the embodiment of the interaction between teaching and learning. To realize the "intelligence" and "interaction" in 
intelligent interaction, a variety of elements are required, including personnel, teaching conditions and environment. In the college English smart classroom, the personnel elements include teachers and students; the teaching condition elements include computers, projectors, teachers and students' mobile terminal equipment. Smart phones are the most common mobile terminal equipment for teachers and students. Due to the wide signal coverage, portability and mobility, smart phones have become effective tools for classroom interactive activities. To realize intelligent interaction in teaching, it is necessary to choose appropriate software or platform. Both teaching software or teaching platform have teaching functions, which can realize the digital presentation of teaching content, flexible storage of teaching resources, comprehensive records of learning processes, and accurate academic reports. Analysis etc. Environmental factors mainly refer to the comprehensive coverage of the network. The elements of the intelligent interaction mode interact in the network environment. There are direct interactions between teachers and students, as well as between teachers and students, and between students and students. Communication and interaction are realized through the interaction of mobile terminals and smart technology.

\subsection{College English Intelligent Interactive Mode Application Based on Chaoxing Learning Link}

The smart teaching software or platforms used in smart classrooms are not the same. At present, the most widely used smart soft wares include Chaoxing Xuetong, Rain Class, Lanmoyun Class, etc. These different wisdomteaching soft wares differ in function and focus due to design requirements. This article uses Chaoxing Xuetong as a smart classroom teaching software and management platform to specifically analyze the interactive behavior in the process of college English teaching. Chaoxing Learning Link is a mobile learning platform for smart phones, tablet computers and other mobile terminals. On this platform, users can search and download electronic resources, and can realize a series of interactive learning activities such as learning school courses and group discussions. Superstar Learning Link is a course learning, knowledge dissemination and management-sharing platform based on micro-service architecture. It has a large number of books, periodicals, newspapers, videos and other resources. It integrates knowledge management, course learning, topic creation, and office applications. Users provide a one-stop learning and working environment.

First, teachers and students download and install the Chaoxing Xuexitong software on the mobile terminal, namely the smart phone. The teacher creates courses in the Chaoxing Xuexitong software on the mobile terminal, such as college English and then establishes the class to form the class invitation code. Then, the students pass to enter the Learn tong class by filling in or scanning the invitation code on the mobile phone learning channel software; at this moment, teachers and students have established a smart connection through the smart tool learning channel, and the intelligent interactive mode of college English teaching is opened.

College English teaching in a smart environment is generally divided into three parts: before class, during class and after class. The main tasks of teachers and students are shown in Table 2.

Table 2 Task list of each link in the smart classroom

\begin{tabular}{|c|c|c|}
\hline link & teacher & student \\
\hline Before class & $\begin{array}{l}\text { Push learning } \\
\text { content } \\
\text { Preparatory Quiz } \\
\text { Analysis } \\
\text { Develop teaching } \\
\text { plan }\end{array}$ & $\begin{array}{l}\text { Self-learning } \\
\text { Preview test } \\
\text { interact }\end{array}$ \\
\hline In class & $\begin{array}{l}\text { Lead discussion } \\
\text { Assign a task } \\
\text { Accurate reviews } \\
\text { Summary feedback }\end{array}$ & $\begin{array}{l}\text { Speak independently } \\
\text { Cooperative inquiry } \\
\text { Show results } \\
\text { interact }\end{array}$ \\
\hline After class & $\begin{array}{l}\text { Design assignment } \\
\text { Academic analysis } \\
\text { Key guidance }\end{array}$ & $\begin{array}{l}\text { finish homework } \\
\text { Check the gaps } \\
\text { Self-learning }\end{array}$ \\
\hline
\end{tabular}

- Interaction before class. The teacher records the college English learning materials and learning content that students need to complete before class into micro-class videos through text, ppt, and video, and uploads them to Chaoxing Learning Tong "Data", and enters the teaching content in the chapter order or class time order into the "chapter" In the "module", students open the mobile terminal learning communication software to enter the course, view the learning content and materials in the "data" and "chapter" modules on the main interface, and conduct independent learning. During the learning process, confusion and communication can be posted through the "discussion" area or private chat with teachers. The use of smart technology and mobile terminals allows people to interact with each other, breaking through the limitations of time and space in the original interaction mode, and realizing the possibility of multiple people interacting at the same time and in different places. In this link, in addition to publishing learning materials, teachers can also publish self-study test through the learning communication platform, and students can get immediate feedback after completing the test. Intelligent technology will record the data and form the academic report. After consulting the academic report, teachers can formulate more targeted and personalized teaching plans.

- Interaction in class. After entering the classroom, teachers can use the "sign-in" control to understand the attendance rate of students. Students can sign in by scanning codes, gestures, and taking photos as required. Smart sign-in can save time and prevent fraud. After entering the teaching session, teachers can use the various class controls on the mobile terminal learning software to create English learning situations and create interactive learning opportunities for students. Such as the use of "group tasks" for role-playing interactive methods, "topic discussion" for in-depth discussion and interactive methods for expressing opinions, "questionnaires" and 
"voting" for mutual evaluation interactive methods, and "tests" to check the effectiveness of learning The interactive method uses "student feedback" to obtain assignments or tasks such as student evaluations. These controls realize intelligent interaction in college English classrooms and effectively promote students' deep learning.

- Interaction after class. After class, teachers use the learning software to assign homework and cooperative exploration tasks, or push task points in the "chapter" module to help students consolidate their knowledge. Students submit the completed results through the corresponding functional modules of the Learning Pass, and obtain teacher evaluation and feedback. Class reports, academic statistics and performance statistics in "Statistics" can effectively reflect the situation of students' knowledge acquisition and skill mastery. In the college English intelligent interactive mode, all data in "statistics" is based on the monitoring of the entire learning process of students. It can be said that intelligent technology runs through the entire learning process of students, including test scores, group task performance, number of answers, and homework completion. Circumstances, completion ratio of task points, online learning retrieval information, etc. The data recorded through intelligent technology can help teachers accurately analyze students' learning behaviors and interactive effects, such as the mastery of students' knowledge points, learning initiative, teamwork, etc., and also help students clearly understand their own The learning effect effectively promotes the development of personalized learning.

\section{Conclusion}

With the rapid development of smart technology, smart tools or platforms are being used more and more frequently in college English teaching, helping college English teaching break through the limitations of previous interaction modes and achieve higher interaction goals of intelligence. The intelligent interaction mode is studentcentered and meets the needs of students' English acquisition and personalized development; it helps teachers enrich the classroom organization, quickly grasp the learning situation, and promote good teacher-student interaction. The intelligent interactive mode extends college English teaching from classroom to extracurricular, and effectively promotes the development of college English teaching in the direction of intelligence and individualization. While improving their personal information literacy, the students should also actively cooperate with English teachers' classroom and extracurricular learning activities, make reasonable use of their learning time, and actively participate in the learning practice of the English intelligent interactive mode. The students should also enhance individual self-learning ability and self-control ability to improve the efficiency of English learning, thereby improving their comprehensive English ability, especially listening and speaking ability.

\section{ACKNOWLEDGMENTS}

This article is supported by the Youth Fund Project of Wuhan Donghu Academy of Sciences in 2019, "Research on Product Recommendation Based on Web Space-Time Customer Behavior Trajectory" < No: 2019dhzk006>.

\section{References}

1. Sun Shuhui, Liu Bangqi. (2015)Smart Classroom Model Based on Dynamic Learning Data Analysis. China Education Information, 22: 68-72.

2. Rong Fang.(2014) Interactive Research on the Cultivation of College Students' English Practical Ability Based on the Perspective of Social Network Analysis[J]. Foreign Language Audio-visual Teaching, 6:165-168.

3. Zhang Jiajie, Dong Yan. (2019) The Application and Practice of New Interactive Mechanism in College English Teaching. Research on Heilongjiang Higher Education, 2:120-125.

4. Li Zhen. (2015)The Application of Interactive Language Teaching in Higher Vocational English Teaching. Vocational Education Newsletter, 12:98102.

5. Li Xi. (2016) Constructing a New Mode of College English Teaching under the Theory of Multiple Intelligences. Journal of Hunan University of Science and Technology, 3: 157-158.

6. Cheng Weijuan, Li Xiaorong.(2020) Research on College English Vocabulary Online Teaching Based on Multiple Intelligence Theory. Heike Academic Journal, 6: 105-106.

7. Liu Bangqi. (2016)Research on Smart Classroom Teaching Design and Implementation Strategy in the "Internet+" Era. China Audio-visual Education, (2): 18-20.

8. Chen Ting. (2017)Research on the Design and Application of Smart Classroom Teaching Mode under the Background of "Internet + education". Jiangsu Normal University, 6: 22-23.

9. Sun Shuhui.(2017) Smart classroom model based on dynamic learning data analysis. China Education Informatization, 4: 66-67.

10. Xu Lifei.(2018) The design and application of smart classroom teaching mode under big data environment. Hebei Normal University, 3: 150-151. 